\title{
Analysis of Carbonation in Mortars made with Solid Waste as a Substitute for Cement
}

\author{
W. Martinez Molina, E. M. Alonso Guzman, H. L. \\ Chavez Garcia, C. Lara Gomez, F. M. Gonzalez \\ Valdez, \\ Department of Materials, Faculty of Civil Engineering \\ University of San Nicolas de Hidalgo \\ Morelia, Michoacan, Mexico \\ wilfridomartinezmolina@gmail.com, \\ eliamercedesalonso@gmail.com, \\ hchavezenator@gmail.com, cindylago@hotmail.com, \\ laboratoriomaterialesfic@gmail.com,
}

T. Perez Lopez, J. Reyes Trujeque, J. Tamayo Zapata

Autonomous University of Campeche

Campeche, Mexico

J. T. Pérez Quiroz

Mexican Transport Research Institute

Ministry of Communications and Transports

Sanfandila, Pedro Escobedo, Queretaro, Mexico

jtperez@imt.mx

\author{
H. Hernandez Barrios \\ Department of Structures, Faculty of Civil Engineering \\ University of San Nicolas de Hidalgo \\ Morelia, Michoacan, Mexico \\ hugohernandezbarrios@yahoo.com.mx \\ W. Martinez Alonso \\ Division of Civil and Geomatics Engineering, Faculty of \\ Engineering, National Autonomous University of Mexico \\ Mexico City, Mexico and \\ Texas University, Austin, United States \\ wilfrido.martinez.alonso@gmail.com
}

\author{
J. A. Bedolla Arroyo \\ Faculty of Architecture \\ University of San Nicolas de Hidalgo \\ Morelia, Michoacan, Mexico \\ bedollaalberto@gmail.com
}

\begin{abstract}
This research evaluates the behaviour of Portland cement-based mortars with additives that act as cementing materials. These additions are silica rich materials used as substitutes for PC (Portland cement type IV ASTM) in the preparation of mortars, as an alternative to reduce the amount of cement, reusing agribusiness waste. The results indicate that the use of some additions in the percentages specified herein is not convenient to mitigate the phenomenon of carbonation, since as the degree of substitution increases, the speed also increases carbonation. On the other hand, if the emission of polluting particles into the environment is mitigated, the amount of cement used in the mortar decreases.
\end{abstract}

Keywords—solid waste substitute; mortars cement; carbonation

\section{INTRODUCTION}

In nature, the $\mathrm{CO}_{2}$ present in the atmosphere and the lithosphere (soil and water), when combined with water produces $\mathrm{H}_{2} \mathrm{CO}_{3}$, which generates a $\mathrm{pH}$ reduction. This is deleterious to sedimentary rocks (limestone), as it promotes its dissolution, forming bicarbonate ions $\left(\mathrm{HCO}_{3}-\right)$ [3].

One of the main environmental concerns since the late twentieth century is global warming, which is the temperature increase on the planet. As a result, climate change is predicted to affect the stability of existing ecosystems and thus the species that inhabit them are threatened. The gases that are targeted to cause this phenomenon are methane $\left(\mathrm{CH}_{4}\right)$, nitrous

The authors acknowledge the financial support of the Coordination of Scientific Research of the Universidad Michoacana de San Nicolás de Hidalgo and Materials Thematic Network for Artistic and Historical Interest Promep SEP and CONACYT (project CB-2008-01101891). oxides $\left(\mathrm{N}_{\mathrm{x}} \mathrm{O}_{\mathrm{y}}\right)$ and $\mathrm{CO}_{2}$, among others.

The construction building material used in the greatest quantities is currently concrete. This is because of its versatility in terms of the geometric shape that it can adopt and its application either on site or prefabricated. It is composed of cement, coarse aggregate (gravel), fine aggregate (sand) [1, 2], water and sometimes additives and additions that encourage the hardening material to form a compact appearance; also, cement-based mortar is the most commonly used material, and so is the focus in this paper.

Cement is the binder component in the concrete/mortar, so the specific final properties depend largely on its quality and dosage. This material is obtained by calcining limestone with clay in a kiln. In this process, the limestone releases $\mathrm{CO}_{2}$ into the atmosphere. Furthermore, the $\mathrm{CO}_{2}$ produced by the combustion of hydrocarbons to reach the calcination temperature leads to the generation of close to one ton of $\mathrm{CO}_{2}$ per ton of cement. By mixing the cement with water, compounds are produced that provide rigidity and coalesce with other components into a solid mass. As reaction products, calcium hydroxide $\left(\mathrm{Ca}(\mathrm{OH})_{2}\right)$, sodium hydroxide $(\mathrm{NaOH})$ and potassium hydroxide $(\mathrm{KOH})$ are generated, giving it an alkaline $\mathrm{pH}$ close to 12.5 [3].

The preparation of mortar requires a dosage of water for the cement compounds to react fully. Excess water is trapped in the rigid paste, causing pores to fill with water. The solution in 
the pores acquires an alkaline $\mathrm{pH}$ by dissolving the hydroxides produced from the reaction of cement with water [2].

\section{A. Carbonation Process}

The water contained in the pores of the concrete is able to dissolve the $\mathrm{CO}_{2}$ in the atmosphere forming $\mathrm{H}_{2} \mathrm{CO}_{3}$, an acid which is combined with alkali in a neutralization reaction by reducing the $\mathrm{pH}$ of the solution [5].

$$
\begin{aligned}
& \mathrm{CO}_{2}+\mathrm{H}_{2} \mathrm{O}+2 \mathrm{H}+\mathrm{CO} 32-[1] \\
& \mathrm{Na}++\mathrm{OH}-\mathrm{NaOH}[2] \\
& \mathrm{KOH} \mathrm{K}++\mathrm{OH}-[3] \\
& \mathrm{Ca}(\mathrm{OH})_{2}+\mathrm{Ca}_{2}+2 \mathrm{OH}-[4] \\
& 2 \mathrm{NaOH}+\mathrm{CO}_{2} \mathrm{Na}_{2} \mathrm{CO}_{3}+\mathrm{H}_{2} \mathrm{O}+2 \mathrm{H}_{2} \mathrm{O}[5] \\
& 2 \mathrm{KOH} \mathrm{K} \mathrm{CO}_{3}+\mathrm{H}_{2} \mathrm{O}+\mathrm{CO}_{2}+2 \mathrm{H}_{2} \mathrm{O}[6] \\
& \mathrm{Ca}(\mathrm{OH}) 2 \mathrm{CaCO}_{3}+\mathrm{H}_{2} \mathrm{O}+\mathrm{CO}_{2}+2 \mathrm{H}_{2} \mathrm{O}[7]
\end{aligned}
$$

As the compound formed at the end is $\mathrm{CaCO}_{3}$, it is called the carbonation process.

Due to the porosity of the concrete and relative humidity conditions in the exposure environment, the pores may encounter different filling conditions. In the case of saturation of the pore, the transportation of carbon dioxide $\left(\mathrm{CO}_{2}\right)$ occurs by diffusion, being a very a slow progress in the order of 8 $10 \mathrm{~cm}^{2} / \mathrm{s}$, causing no deterioration risk to the concrete by carbonation. When the relative humidity is very low, as in arid and semi-arid areas, the amount of water retained in the pores is not sufficient for carbonation to occur. The most favourable conditions for the progress of the carbonation occurs when the relative humidity of the medium is in the range 60 to $75 \%$. Thus, it is seen that the carbonation phenomenon is strongly linked to weather conditions such as high relative humidity, temperature, and rainfall, among others, which determine the pore filling and thereby the advancement of the carbonation $[3,5]$.

\section{B. Measuring progress of carbonation.}

The visual way to measure a change in $\mathrm{pH}$ is with the use of acid-base indicators, which change colour at certain $\mathrm{pH}$ ranges. The carbonation effect, in particular, the $\mathrm{pH}$, can range from 12.5 to near 8 . Phenolphthalein indicator presents a violet colour at $\mathrm{pH}$ values greater than 10 and is colourless at $\mathrm{pH}$ values less than 8.3. $\mathrm{CO}_{2}$ is a compound essential for life, but it also produces adverse effects on the ecosystem and on the stability and durability of civil works constructed of reinforced concrete [5].

\section{EXPERIMENTAL PROCEDURE}

A regional field study was conducted to ascertain the most abundant solid waste and the need for producers to remove it without further investment. The residues were characterized in terms of their use as building materials and their mechanical effects on the cement mortar base, also their pozzolan effect. The additions were studied as replacements of Portland cement in different percentages [2, 3].
The additions were agro-industrial waste used as furnace bottom ash CBOF 15\% (coke oven blast furnace, Arcelor Mittal, Mexico); CEL 5\% ash brick making (ash brick making annealed clay handmade Santiago Undameo, Mexico); CM 15\% coal (Arcelor Mittal, Mexico), and 15\% blast furnace slag EAH (Arcelor Mittal, Mexico). All of them were compared against two controls made with cement CPC $30 \mathrm{R}$ RS, comparable to PC ASTM C-150 Type IV. Control one, T1 standard, was developed with silica sand from Rio Lerma, State of Mexico, Mexico; control 2, T2, was made from silica sand from the Huajumbaro River, Michoacan, Mexico [3], the sands were then LERM and HUAJ.

The sands were sampled from the quarry stones of the

\begin{tabular}{|c|c|c|c|}
\hline Test & Standard & $\begin{array}{l}\text { Lerma } \\
\text { Sand }\end{array}$ & $\begin{array}{c}\text { Huajumbaro } \\
\text { Sand }\end{array}$ \\
\hline Sampling & ASTM D-75 & $250 \mathrm{kgf}$ & $250 \mathrm{kgf}$ \\
\hline Reducing samples & ASTM C-702 & $0.500 \mathrm{kgf}$ & $0.500 \mathrm{kgf}$ \\
\hline $\begin{array}{l}\text { Bulk density (unit } \\
\text { weight) and voids }\end{array}$ & $\begin{array}{c}\text { ASTM C-29/ } \\
\text { C-29M }\end{array}$ & 1.353 & 1.226 \\
\hline $\begin{array}{l}\text { Bulk density (unit } \\
\text { weight) }\end{array}$ & $\begin{array}{c}\text { ASTM C-29/ } \\
\text { C-29M }\end{array}$ & 1.444 & 1.331 \\
\hline Relative density & ASTM C-128 & 2.40 & 2.31 \\
\hline Specific gravity & ASTM C-128 & $2.39-2.48$ & $2.24-2.36$ \\
\hline Surface moisture (\%) & $\begin{array}{l}\text { ASTM C- } \\
128, C-70\end{array}$ & 0.748 & 0.741 \\
\hline Absorption percentage & $\begin{array}{l}\text { ASTM C- } \\
128, \text { C-566 }\end{array}$ & 1.89 & 3.18 \\
\hline $\begin{array}{c}\text { Sand equivalent value } \\
(\%)\end{array}$ & $\begin{array}{l}\text { ASTM D- } \\
2419\end{array}$ & 86.97 & 98.25 \\
\hline $\begin{array}{c}\text { Clay lumps and friable } \\
\text { particles (\%) }\end{array}$ & ASTM C-142 & 8.165 & 2.498 \\
\hline
\end{tabular}
rivers mentioned in the dry season, then moved to the materials laboratory at Ing. Luis Silva Ruelas where characterization tests were performed as specified in ASTM. All tests were performed in triplicate and the values given are the average of three quantifications.

TABLE I. PHYSICAL TESTING OF AGGREGATES

\section{A. Preparation of the samples.}

Preparation of the mortars was conducted under laboratory conditions, dosed by weight, mechanically mixed with clean water. Specimens that were developed were cylinders of $5 \mathrm{~cm}$ x $\varnothing 10 \mathrm{~cm} \mathrm{~h}$. All specimens were cured after uncentred immersion [4, 12].

Hardened mortar specimens were tested using nondestructive VPU (ultrasonic pulse velocity) for resistivity, porosity, density and apparent specific gravity; they were also subjected to destructive testing such as simple compression, tension, bending and modulus of rupture and carbonation damage. The values (not included in this study) were decisive in choosing the percentages of substitution of cement by the various additions or waste $[1,6]$. 
TABLE II. TESTS ON SPECIMENS OF MORTAR

\begin{tabular}{|c|c|}
\hline Test & Standard \\
\hline Flow table (\%) & ASTM C-230/230M \\
\hline Compressive strength & ASTM C-109 \\
\hline Tensile strength & ASTM C-307 \\
\hline Flexural strength & ASTM C-348 \\
\hline Density (unit weight) & ASTM C-29, C-138 \\
\hline Pulse velocity & ASTM C-597 \\
\hline Density, absorption and voids (\%) & ASTM C-642 \\
\hline Carbonation, corrosion potentials of \\
uncoated reinforcing steel in concrete
\end{tabular}

TABLE III. TESTS RX FLUORESCENCE

\begin{tabular}{|c|c|c|c|c|c|c|c|c|c|c|c|c|c|}
\hline$S$ & $\mathrm{SiO}_{2}$ & $\mathrm{TiO}_{2}$ & $\mathbf{A l}_{2} \mathbf{O}_{3}$ & $\mathrm{Fe}_{2} \mathrm{O}_{3}$ & MnO & MgO & $\mathrm{CaO}$ & $\mathrm{Na}_{2} \mathrm{O}$ & $\mathrm{K}_{2} \mathrm{O}$ & $\mathbf{P}_{2} \mathbf{O}_{5}$ & $\mathrm{SO}_{3}$ & PXC & Tot \\
\hline CEL & 19.1 & 0.32 & 8.776 & 2.008 & 0.53 & 4.243 & 27.87 & 0.545 & 6.05 & 1.76 & 0.8 & 27.3 & 98.5 \\
\hline EAH & 36.38 & 0.56 & 10.63 & 0.335 & 0.41 & 10.107 & 37.551 & 0.298 & 0.42 & 0.05 & 1.93 & 0.72 & 96 \\
\hline $\mathrm{CF}$ & 14.58 & 0.83 & 4.287 & 26.77 & 2.42 & 5.995 & 37.45 & 0.032 & 0.02 & 0.81 & 0.8 & 4.79 & 98 \\
\hline CPC & 27.93 & 0.2 & 6.437 & 2.217 & 0.08 & 1.301 & 49.77 & 0.669 & 1.25 & 0.11 & 3.37 & 5.12 & 95.1 \\
\hline $\mathrm{CM}$ & \multicolumn{13}{|c|}{ Calcination Lost 86\% } \\
\hline HUAJ & 78.19 & 0.2 & 11.56 & 1.567 & 0.03 & 0.239 & 1.01 & 2.666 & 3.57 & 0.03 & - & 1.19 & 100 \\
\hline LERM & 76.41 & 0.3 & 11.295 & 2.536 & 0.02 & 0.5235 & 1.41 & 2.2255 & 3.10 & 0.07 & - & 2.35 & 55.15 \\
\hline S & $\mathrm{SiO}_{2}$ & $\mathrm{TiO}_{2}$ & $\mathrm{Al}_{2} \mathrm{O}_{3}$ & $\mathrm{Fe}_{2} \mathrm{O}_{3}$ & $\mathrm{MnO}$ & $\mathrm{MgO}$ & $\mathrm{CaO}$ & $\mathrm{Na}_{2} \mathrm{O}$ & $\mathrm{K}_{2} \mathrm{O}$ & $\mathrm{P}_{2} \mathrm{O}_{5}$ & $\mathrm{SO}_{3}$ & PXC & Tot \\
\hline CEL & 19.1 & 0.32 & 8.776 & 2.008 & 0.53 & 4.243 & 27.87 & 0.545 & 6.05 & 1.76 & 0.8 & 27.3 & 98.5 \\
\hline EAH & 36.38 & 0.56 & 10.63 & 0.335 & 0.41 & 10.107 & 37.55 & 0.298 & 0.42 & 0.05 & 1.93 & 0.72 & 96 \\
\hline
\end{tabular}

\section{B. Carbonation test.}

A series of five cylinders of $5 \mathrm{~cm}$ diameter and $10 \mathrm{~cm}$ length were placed in an accelerated carbonation chamber at $25+/-$ $2{ }^{\circ} \mathrm{C}, 65+/-5 \%$ relative humidity and $3 \% \mathrm{CO}_{2}$-approximately 100 times the amount in the natural environment $(\sim 0.03 \%)-$ in order to obtain information in a compressed carbonation process. The circular faces of the samples were covered with paint to limit the progress of carbonation longitudinally. They were cut into $5 \mathrm{~mm}$ sections and subjected to $30,60,75,90,120$ and 180 days of exposure. After each cut, the indicators for measuring the carbonation front applied $[5,7,8,10,11]$

\section{RESUlTS AND DiSCUSSION}

\section{A. Characterization phase of cement substitutes.}

TABLE IV. THE POZZOLANIC ACTIVITY, VERIFIED IN ACCORDANCE WITH ASTM C 618-12 [12] CAREFULLY INSPECTING THE CONTENTS $\left(\mathrm{SIO}_{2}+\mathrm{AL}_{2} \mathrm{O}_{3}\right)$ TO DESCRIBE THE ACIDITY OF THE POZZOLANIC MATERIAL.

\begin{tabular}{|c|c|c|c|c|c|c|}
\hline Sample & & $\mathrm{SiO}_{2}$ & $\mathbf{A l}_{2} \mathbf{O}_{3}$ & $\mathrm{Fe}_{2} \mathrm{O}_{3}$ & $\begin{array}{c}\text { C } \\
\text { Pozzol } \\
\text { anic }\end{array}$ & $\begin{array}{c}\text { Acid } \\
\text { Charact } \\
\text { er } \\
\end{array}$ \\
\hline Addition & CEL & 19.1 & 8.776 & 2.008 & 29.884 & 27.876 \\
\hline Addition & CPC & 27.93 & 6.437 & 2.217 & 36.584 & 34.367 \\
\hline Addition & $\mathrm{CF}$ & 14.58 & 4.287 & 26.77 & 45.637 & 18.867 \\
\hline Addition & EAH & 36.38 & 10.63 & 0.335 & 47.345 & 47.01 \\
\hline Addition & CEL & 19.1 & 8.776 & 2.008 & 29.884 & 27.876 \\
\hline PC & CPC & 27.93 & 6.437 & 2.217 & 36.584 & 34.367 \\
\hline Addition & $\mathrm{CF}$ & 14.58 & 4.287 & 26.77 & 45.637 & 18.867 \\
\hline Addition & EAH & 36.38 & 10.63 & 0.335 & 47.345 & 47.01 \\
\hline Sand & $\begin{array}{c}\text { LERM } \\
\text { T1 }\end{array}$ & 76.41 & 11.30 & 2.537 & 90.242 & 87.705 \\
\hline Sand & $\begin{array}{c}\text { HUAJ } \\
\text { T2 }\end{array}$ & 78.19 & 11.56 & 1.567 & 91.317 & 90.75 \\
\hline
\end{tabular}

Pozzolanic reaction consumes alkali compounds present in the pore solution and can generate a decrease in $\mathrm{pH}$. As for alkali generation, EHA and $\mathrm{CBOF}$ are high in $\mathrm{MgO}$ and $\mathrm{CaO}$. The presence of these compounds in water can be a source of generation of the corresponding alkali to maintain the $\mathrm{pH}$ of the pore solution in values greater than 12 , even after the pozzolanic reactions.

TABLE V. ELEMENTAL ANALYSIS

\begin{tabular}{|c|c|c|c|c|c|c|c|c|c|c|c|c|c|c|}
\hline Sample & $\mathbf{R b}$ & $\mathbf{S r}$ & $\mathbf{B a}$ & $\mathbf{Y}$ & $\mathbf{Z r}$ & $\mathbf{N b}$ & $\mathbf{V}$ & $\mathbf{C r}$ & $\mathbf{C o}$ & $\mathbf{N i}$ & $\mathbf{C u}$ & $\mathbf{Z n}$ & $\mathbf{T h}$ & $\mathbf{P b}$ \\
\hline CM & 30 & 154 & 452 & 30 & 138 & - & 197 & 106 & 32 & 72 & 149 & 106 & 12 & 13 \\
\hline CEL & 86 & 999 & 958 & 13 & 141 & 3 & 58 & 62 & 7 & 16 & 138 & 192 & 8 & 8 \\
\hline EAH & 8 & 326 & 265 & 11 & 125 & 1 & 48 & 6 & 1 & 5 & 45 & $<2$ & 4 & 8 \\
\hline CF & 4 & 139 & 55 & 2 & 89 & 40 & 2146 & 546 & 36 & 9 & 87 & 45 & $<3$ & 19 \\
\hline PC & 30 & 326 & 81 & 6 & 59 & 3 & 75 & 46 & 4 & 19 & 62 & 326 & $<3$ & 38 \\
\hline HUAJ & 127 & 81 & 461 & 25 & 41 & $<1$ & $<5$ & 186 & 27 & 12 & 13 & 28 & 9 & 16 \\
\hline LERM & 119.5 & 209.5 & 769 & 40 & 138 & - & 43 & 19.5 & 11.5 & 12 & 9.5 & 55.5 & 10.5 & 24 \\
\hline
\end{tabular}




\section{B. Carbonation.}

Fig. 1 shows the progress of carbonation of front mortar samples under study. It shows that all samples were fully carbonated over a period of 180 days. Those of $25 \%$ CBOF and $15 \%$ CEL took 75 days to be carbonated; 90 days and 120 days were required by TI and T2 carbonated samples respectively, while 15\% EHA samples achieved complete carbonation after 180 days. The $15 \%$ CM did not react: this is explained by it being a component of organic type, so no pozzolanic activity occupies the space in the pores $[10,11,13]$.

The 15\% EAH specimens (CaO, MgO, 10, 107, 37, 551) required more time to be carbonated.

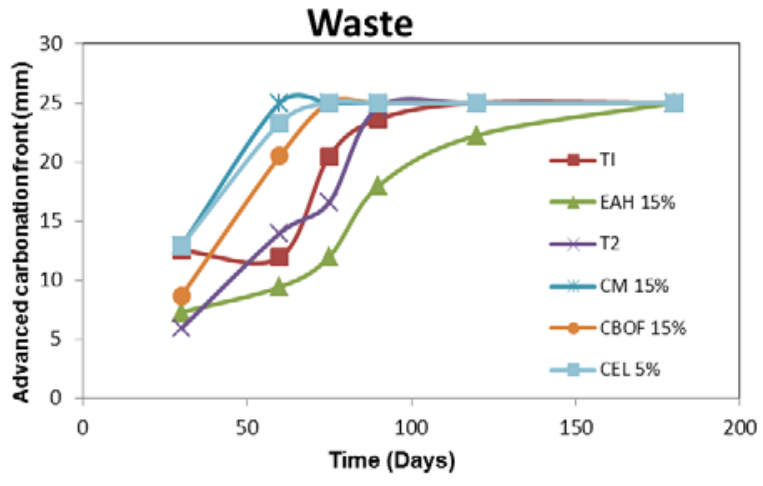

Fig. 1. Advanced carbonation front

Fig. 1 shows the trend of carbonation constant over time according to the (1):

$$
\mathrm{e}=\mathrm{kt}^{1 / 2}
$$

where, e is the thickness of carbonation front, $\mathrm{t}$ is time and $\mathrm{k}$ the proportionality constant.

$\mathrm{K}$ is a quality parameter of a mixture. It is observed that only $15 \%$ EAH specimens are of higher quality, according to this criterion. The two controls have close to $20 \%$ deviation, as a result of using two different fine aggregate values [13].

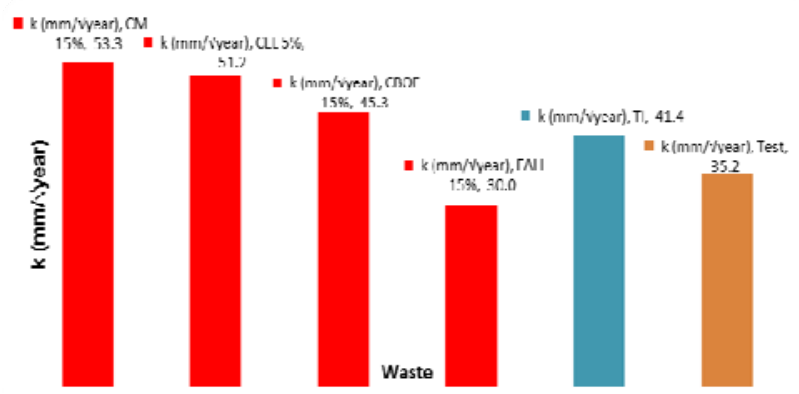

Fig. 2. K values for each group of specimens

\section{CONCLUSIONS}

The waste mortars additions in the form of Portland cement substitution do cause improvement in the mixtures vulnerable to attack by carbonation. Portland cement mixtures consuming smaller amounts of additions caused decreased emissions in environmental contaminants. Cases of waste materials present the least pollution abatement.

Substituting materials in Portland cement requires further consideration from the standpoint of reducing costs and emissions and increasing durability such as resistance to attack by carbonation; however, materials can also be added to mixtures not as substitutions but as cement additives to modify the properties of the mixtures. This too can result in a decreased carbon footprint, achieving a longer the lifespan and decreasing the need for demolition and repairs.

\section{REFERENCES}

[1] S.C. Arguello Hernández, "Comparative analysis between nondestructive and destructive techniques applied to mineral mortars substitutions high temperature, organic and inorganic ash, industrial waste and cactus fibers. Master's thesis: Fac. Ing. Civil, UMSNH, Morelia, Mexico, 2012.

[2] M. Sanchez Arreola, Organic ash pozzolanic activity (agro-products) to improve the durability of concrete in bridges. Master's thesis: Fac. Ing. Civil, UMSNH, Morelia, Mexico, 2013.

[3] C. Bernabe Reyes, Evaluation of cement mortars replaced with pozzolanic ash to mitigate the phenomenon of corrosion in concrete structures rehabilitation. Master's thesis: Fac. Ing. Civil, UMSNH, Morelia, Mexico, 2015.

[4] Building Code Requirements for Structural Concrete (ACI 318-08) and Commentary: An ACI Standard Reported by ACI Committee 318M.

[5] E. Chavez-Ulloa, T.P. Lopez, J.R. Trujeque, and F.C. Perez, "Deterioration of concrete structures due to carbonation in the tropical marine environment and accelerated carbonation chamber”, Tech. J. Facul. Eng. Univ. Zulia, vol. 36, pp. 104-113, 2015.

[6] J.I. Escalante, A. Navarro, and L.Y. Gómez, "Characterisation of Portland cement mortars metakaolin replaced by low purity”, ALCONPAT J. vol. 1, pp. 156-169, 2011.

[7] P. Helene, and P. Castro, "A novel method to predict concrete carbonation”, Cement. Concrete. Res. Dev. vol. 1, pp. 25-35, 2009.

[8] V.M. Malhotra, and P.K. Mehta, Pozzolanic, and cementitious materials. Ottawa, Canada: Gordon and Breach Publishers, 1996.

[9] E. Moreno, R. Solis Aportela, and L. Pardo, "Characterization of ash from Popocatepetl volcano and its application as a cementitious material in its natural state”, Constr. Eng. J. vol. 19, pp. 127-134, 2004.

[10] A. Morandeau, M. Thiery, and P. Dangla, "Impact of accelerated carbonation on OPC cement paste blended with fly ash", Cement. Concrete. Res. vol. 67, pp. 226-236, 2015.

[11] A. Morandeau, M. Thiery, and P. Dangla, "Investigation of the mechanism of carbonation $\mathrm{CH}$ and $\mathrm{CSH}$ in terms of kinetics, microstructure changes, and moisture properties", Cement. Concrete. Res. vol. 56, pp. 153-170, 2014.

[12] NMX-C-414-ONNCCE-2010. Construction industry - Hydraulic Cement - Specifications and test methods.

[13] Rincon Troconis O./International Coordinator DURACON; Bolivia (Montenegro, J.C.); Chile (Vera, R.Carvajal, A.M.);Colobia (Gutierrez, R.M., Del Vasto, S.);Costa Rica (Saborio, E,); Mexico (Torres-Acosta, A., Perez Quiroz, J., Martinez-Madrid, M., Almeraya, F., GaonaTiburcio, C., Castro-Borges, P., Moreno, El, Perez-Lopez, T.MartinezMolina, W., Alonso-Gomez, E.); Portugal (Salta, M, de Melo, A. P..); Spain (Martinez , I. Revolledo, N.); Uruguay (Rodriguez, G.,Pedrón, M.); Venezuela (Millano, V. Sanchez, M. Of the Items, E.). Early publication, "Concrete carbonation in Ibero-American Countries DURACON Projet: Six-year Evaluation” NACE International Corrosion, DOI: 10.5006/1385, 2014. 